\title{
ROUSSEAU E A ARTE DE OBSERVAR E JULGAR OS HOMENS
}

Claudio Araujo Reis*

RESUMO $O$ artigo examina o que está envolvido no processo de conhecer e julgar outras pessoas, questão central para a compreensão do projeto autobiográfico de Rousseau. Isso é feito sobretudo a partir da análise de algumas figuras de "observadores" que encontramos na obra de Rousseau: o "Rousseau” dos Dialogues, Émile, Saint-Preux e Wolmar.

ABSTRACT This article examines an important question for the adequate comprehension of Rousseau's autobiographical project: what is involved in the process of getting to know and passing judgements on other people? Special attention is given to some examples of "observers of men" which can be found in Rousseau's works: the "Rousseau" character in the Dialogues, Émile, Saint-Preux and Wolmar.

Palavras-chave Rousseau, autobiografia, imparcialidade, juizo moral, sensibilidade

O objetivo deste artigo é apresentar algumas reflexões sobre o que em geral está envolvido, segundo Rousseau, em um tipo de juízo sobre si mesmo e sobre os outros, implicado pelo conhecimento de si mesmo e dos outros, a partir, sobretudo, da análise de elementos presentes em seu projeto autobiográfico. Faremos isso principalmente através do exame das figuras de alguns

* Universidade de Brasília / UnB - Departamento de Filosofia

KRITERION, Belo Horizonte, $n^{0}$ 105, Jun/2002, p.67-96 
"juízes" mais ou menos bem sucedidos em seu esforço de observar e conhecer os homens. Entendendo seu sucesso ou seu fracasso estaremos em condições de avaliar melhor o tipo de juízo de que se ocupam. Começaremos com algumas observações gerais sobre a filosofia de Rousseau e sobre o sentido e o lugar de seu projeto autobiográfico na obra como um todo. Em seguida, faremos uma breve análise da figura do juiz imparcial na obra Rousseau juge de Jean-Jacques: Dialogues ${ }^{1}$, figura representada ali pelo personagem "Rousseau". Por fim, antes de concluirmos, examinaremos três outras figuras de observadores e juízes dos homens: Émile adolescente, Saint-Preux em Paris e o "judicioso" Wolmar.

Rousseau é freqüentemente percebido por seus leitores como um autor desconcertante. Músico, filósofo, romancista, autobiógrafo, suas obras freqüentemente apresentam essa mistura de gêneros. O Émile, como muitas vezes já se notou, começa como tratado filosófico e termina como romance. E toda sua produção, tanto a filosófica quanto a artística, é atravessada por sua personalidade singular e por sua constante reflexão sobre si mesmo. Não raro, as obras autobiográficas fornecem elementos mais ricos para entendermos a posição filosófica geral de Rousseau do que as obras que seus leitores estariam mais prontamente a reconhecer como propriamente "filosóficas".

A filosofia de Rousseau, não seria demais afirmar, é toda ela um apelo ao autoconhecimento. Há, nesse apelo, na medida em que se dirige ao universal — o homem - , uma parte de reverência pela verdade: trata-se de constituir uma ciência do homem, conhecer sua natureza; é o sentido da referência à inscrição délfica no início do Discours sur l'origine de l'inégalité. Mas há também uma parte importante de consolatio: conhecer a si mesmo é reconhecer o que o próprio Rousseau chama de princípio fundamental da moral, isto é, que o homem é naturalmente bom. Conhecer a si mesmo parece conduzir a amar a si mesmo - amor que, a partir daí, pode ambiguamente ter como referente a natureza humana em geral, reconhecida, por exemplo, em sua dignidade, ou aquele centro afetivo que chamamos eu. O problema da philautia está desde o início entranhado na tentativa rousseauniana de constituir uma ciência do homem.

O projeto de Rousseau é o resultado de um entrelaçamento de diferentes focos ou perspectivas sob os quais o homem pode ser olhado. Em particular, o que o caracteriza mais propriamente é uma inflexão da perspectiva mais

1 As referências aos textos de Rousseau remetem à edição das Eurvres complètes, Bibliothèque de la Pléiade. Paris: Gallimard, 1959-1995 (número do volume em romanos, número das páginas em arábico). As trađuções são minhas. 
universal em direção à mais singular ${ }^{2}$. Rousseau começa contando a história do homem (lembremos a exclamação do preâmbulo do segundo Discours: "Ó Homem... eis aqui tua história...") e termina "recitando" Jean-Jacques nas Rêveries. No entanto, é preciso entender que, da forma como ele as articula, não há uma verdadeira descontinuidade entre as duas dimensões: ao contrário, a passagem pelo nível mais singular tem, no final das contas, como que um papel de justificação ou, mesmo, de fundamentação. Sua "conversão" no caminho de Vincennes mostrou-lhe a direção: como para Agostinho, para Rousseau a verdade habita o interior do homem ${ }^{3}$. Vê-la, portanto, já implica o dobrar-se sobre si mesmo. O apelo a entrar em si mesmo é um apelo lançado a cada indivíduo em nome dessa verdade e é em torno dele que a filosofia de Rousseau vai ser construída ${ }^{4}$. Esse caminho para dentro de si e de volta à natureza está aberto para todos. Mas Rousseau está perfeitamente consciente das dificuldades que ergue essa volta sobre si mesmo em busca de uma retomada de contato com a fonte da natureza. Sua obra, do Discours sur l'origine de l'inégalité às Rêveries du promeneur solitaire, poderia toda ela ser lida nestes dois registros: no registro da "ciência do homem" que propõe; no registro pessoal da auto-expressão ${ }^{5}$.

Assim, desde o início, ao propósito de fundar uma ciência do homem baseada no conhecimento da natureza humana, começa a sobrepor-se a perspectiva singular da primeira pessoa. Essa perspectiva ganha ainda um segundo reforço. O esforço que Rousseau pede que seu leitor faça é, por um lado, quase como que um esforço de rememoração. É preciso lembrar que o que hoje parece representar um monstro já foi antes a estátua de um deus. Não é por acaso que as duas primeiras obras de Rousseau — os dois Discours - têm a forma de uma história. Mais um pouco e a "história da alma" de um indivíduo excepcional vai aparecer como uma verdadeira alternativa filosófica. Por outro lado, o leitor ideal de suas obras é aquele que, como o "Rousseau" dos Dialogues, reconhece-se nela como em um espelho (cf. OC I, 728).

2 Ver REIS, C. "Filosofia e terapia". Kriterion, vol. 39, n. 98, julho a dezembro de 1998, pp. 37-76; ver também STAROBINSKI, J. La transparence et I'obstacle, Paris: Gellimard, 1971, p. 50.

3 Sobre isso, ver ainda STAROBINSKI, J. q. cit. , p. 31.

4 Mais ainda: é dessa volta sobre si mesmo, dessa busca da natureza no fundo de seu coração, que Rousseau espera tudo: a "prova" de suas idéias não é outra senão a repercussão delas no "coração" de seus leitores. O vigário saboiano, dirigindo-se a seu jovem discípulo é, podemos dizer, Rousseau dirigindo-se a seus leitores: "il me suffit de vous exposer a que je pense dans la simplicité de mon cour. Consultez le vôtre durant mon discours; C'est tout ce que je vous demande" (OC IV, 566).

5 o próprio Rousseau acentuava essa vinculação homem-obra, no registro mais pessoal possível, como um princípio válido de apreciação de sua obra. Por intermédio do personagem do "Francês", ele diz no terceiro Dialogue: "Son système peut être faux; mais en le developpant il s' est peint lui-même au vrai d'une façon si caractéristique et si sure qu'il m'est impossible de m’y tromper" (OC I, 934). 
O projeto de Rousseau surge da confluência dessas duas perspectivas. Antes de mais nada, sua grande ambição é fazer avançar aquilo que chama "o mais útil e o menos avançado de todos os conhecimentos humanos" (OC III, 122) - a ciência do homem. Conhecer o homem, não se pode esquecer, é conhecer sua natureza - ou seja, no sentido em que Rousseau entende isso, vê-lo "tal como o formou a Natureza". Mas, justamente, onde está essa natureza? Certamente, não mais no atual estado de coisas. E como se não bastasse essa distância que esconde de nós o objeto que mais nos interessaria conhecer, há ainda um outro ponto mais grave. O mais cruel, diz Rousseau, é que nada parece transformar mais o homem do que o conhecimento, de tal maneira que parecemos nos afastar cada vez mais da natureza à medida em que mais fazemos avançar nossa ciência: "é que, em algum sentido", diz ele, "à força de estudar o homem, tornamo-nos incapazes de conhecê-lo" (OC III, 122/123).

A busca dessa natureza escondida, portanto, ergue uma dupla exigência: em primeiro lugar, é preciso saber onde procurá-la; é a natureza do homem que nos interessa, mas qual homem? Em que homem ela é ainda visível? Em segundo lugar, há um problema de acesso: como (re)conhecer algo que escapa à observação direta, algo que parece não existir mais ou que se encontra desfigurada no comportamento atual dos homens que temos sob a vista? Em uma passagem particularmente importante do terceiro Dialogue, Rousseau oferece as chaves para entendermos as várias faces de suas obras e como elas se encaixam para formar e dar unidade a seu projeto:

\footnotetext{
De onde o pintor e apologista da natureza hoje em dia tão desfigurada e caluniada pode ter tirado seu modelo senão de seu próprio coração? Ele a descreveu como se sentia a si mesmo. Os preconceitos a que não estava submetido, as paixões factícias de que não era presa não ofuscavam a seus olhos, como aos olhos dos outros, estes primeiros traços tão geralmente esquecidos ou desconhecidos. Estes traços tão novos para nós e tão verdadeiros, uma vez traçados, encontravam ainda no fundo dos corações a atestação de sua justeza, mas jamais se teriam feito notar por si mesmos se o historiador da natureza não tivesse começado por retirar a ferrugem que os escondia. Apenas uma vida retirada e solitária, um gosto vivo pelo devaneio e pela contemplação, o hábito de entrar em si mesmo e de lá procurar, na calma das paixões, estes primeiros traços desaparecidos na multidão poderiam fazê-lo reencontrá-los. Em uma palavra, era preciso que um homem pintasse a si mesmo para mostrar-nos assim o homem primitivo e se o Autor não fosse tão singular quanto seus livros, jamais ele os teria escrito. (OC I, 936)
}

Fica explícito aqui o entrelaçamento da perspectiva mais universal com a dimensão mais singular. A natureza, desaparecida de toda parte, está no entanto ainda escondida no fundo do coração. Descobrir a verdade sobre a natureza humana, assim, implica retomar contato com a dimensão mais ínti- 
ma do indivíduo. Mais ainda, implica que o indivíduo tenha ele próprio qualidades bem determinadas - gosto pela solidão, pela rêverie e pela contemplação, o hábito de entrar em si mesmo, em suma, a capacidade de uma apreensão profunda de si mesmo. Tão afastados estamos da natureza que só esse mergulho de um indivíduo em sua própria singularidade é capaz de recuperar para todos a natureza humana em sua universalidade.

Mas, ainda assim, pode não parecer totalmente legítima a passagem da preocupação com o universal que é a natureza humana para o estritamente singular que é a história da vida de um indivíduo. Duas outras idéias ajudam a completar essa passagem e acrescentam um terceiro propósito ou uma terceira direção ao projeto de Rousseau. Por um lado, as Confessions, em boa parte, apresentam-se como uma justificativa da singularidade que, para Rousseau, representa sua principal credencial para falar em nome da natureza. Contar sua história parece-lhe a única maneira de fundamentar sua pretensão à absoluta singularidade que, por sua vez, permite-lhe o acesso ao universal da natureza. Mas as Confessions introduzem uma nova nuança no sentido do conhecimento do homem. Ao escrever suas confissões, a motivação imediata de Rousseau era a de corrigir a representação que seus contemporâneos tinham dele próprio. E essa correção importava tanto mais quanto implicava, na verdade, um erro de estimação: o que estava em jogo não era simplesmente um erro de representação, mas um erro de avaliação. Era o verdadeiro valor de Jean-Jacques que não recebia o reconhecimento devido. Assim, um terceiro conjunto de problemas vem associar-se aos outros: o que significa conhecer um homem? E entenda-se por isso: não mais apenas conhecer a natureza humana, não mais apenas conhecer a si mesmo, mas: como conhecer, de modo a poder avaliá-lo e apreciá-lo, um outro que não seja eu mesmo ou que não seja o homem em geral?

O problema do conhecimento do homem para Rousseau delimita-se, assim, por três pontos: de início, no vértice, está a versão mais geral do problema, conhecer a natureza humana, o homem em geral. Mas isso pede a volta sobre si mesmo, a leitura atenta do seu próprio coração, o que inclui, como as Confessions vão mostrar, debruçar-se também sobre as memórias, a infância, a juventude. O terceiro ponto, que se opõe e, ao mesmo tempo, completa os dois outros é o conhecimento dos homens ${ }^{6}$, ou seja, o conhecimento (que inclui um elemento de estimação) dos outros que não eu mesmo. Esse triângulo vai, como

6 Rousseau mais de uma vez opõe o conhecimento do homem ao conhecimento dos homens: ver Essai sur I'origine des langues, (OC V, 394): "Quand on veut étudier les honmes il faut regarder près de soi; mais pour étudier l'hame il faut apprendre à porter sa vüe au loin"; e Dialogues, (OC I, 782) : "Après avoir étudié l'horme toute ma vie j'avois cru comoitre les hammes; je m'étois trompé". 
não poderia deixar de ser, ser fundamental para o desenvolvimento do projeto autobiográfico de Rousseau - para não dizer de toda sua obra.

Em 1770, Rousseau termina de contar a história de sua alma em suas Confessions. Este não era um livro qualquer: era com ele à mão, diz Rousseau, que contava apresentar-se diante do soberano juiz no momento do juízo final. Essa referência apocalíptica parecia dar às Confessions o aspecto de uma última declaração reveladora de toda a verdade antes do silêncio definitivo. No entanto, pouco menos de dois anos depois, Rousseau inicia a redação de seus Dialogues. Que tipo de motivos, afinal, levaram-no a tentar uma nova revelação de si mesmo ${ }^{7}$ ? Será que a tentativa das Confessions ainda ficou aquém do que prometia o seu autor? Será que o ato de auto-apreensão que está em sua origem foi ainda imperfeito?

Jean Starobinski, analisando os problemas da autobiografia em Rousseau, lembra que o conhecimento de si mesmo, para o filósofo genebrino, jamais é um problema, é um dado ${ }^{8}$. O conhecimento de si é intuitivo, o ato de apreender a si mesmo é um "ato de sentimento". Mas esse ato é "indefinidamente renovável". Isso explicaria, pensa Starobinski, por que o empreendimento autobiográfico precisa estar sempre recomeçando, como se partisse a cada vez do nada. Cada auto-apreensão do eu possui como que um novo conteúdo: o eu não se banha duas vezes na mesma corrente de sua vida interior.

Essa hipótese tem o mérito de conseguir conciliar, de um lado, a certeza de Rousseau na sua transparência a si mesmo e na sua capacidade de apreender-se completamente, sem sombras, e, de outro, sua fina percepção das continuidades e descontinuidades do eu. Mas, de certa maneira, ela também mascara as relações que unem e ao mesmo tempo singularizam cada um dos momentos da obra autobiográfica. A multiplicidade dessa obra parece responder a outras necessidades que não apenas a de exprimir outra vez uma nova verdade sobre o eu resultante de um novo ato de sentimento em que o eu apreende-se sob uma luz mais clara (ou, de todo modo, diferente).

De fato, é necessário concordar com a afirmação de que o autoconhecimento jamais aparece a Rousseau como um problema insolúvel. Ainda que tome pouco a pouco consciência das dificuldades implicadas pelo processo de conhecer a si mesmo, não chega nunca ao ponto de desesperar totalmente e concluir que aquilo que ele "é realmente" está irremediavelmente escondido em alguma "profundeza opaca" inacessível e inescrutável. Seu problema

7 Sobre a motivação para a redação dos Dialogues, ver FOUCAULT, Michel, "Introduction", em Rousseau juge de Jean-Jacques. Paris: A. Colin, 1962; O S M O N T, Rdbert, @ I, "Introductions", p. LXIV; GR IMS LEY, Ronald. Jean-Jacques Rousseau, A Study in Self-Awareness. Cardiff: University of wales Press, 1961 p. 232.

8 Q. cit. , p. 216. 
está na outra face da moeda: como fazer o outro ver a mim mesmo como eu me vejo? Como transmitir ao outro o conhecimento tão evidente que tenho de mim mesmo? Desde o início, o problema fundamental de Rousseau é um problema de comunicação - que se agrava consideravelmente após as Confessions. Vejamos como o problema se põe entre as Confessions e os Dialogues. Desde o início, um dos objetivos de Rousseau ao escrever suas Confessions era o de corrigir um erro:

Cada um imaginava-me segundo sua fantasia, sem temer que o original viesse desmenti-lo. Havia um Rousseau no grand monde e um outro, no recolhimento, que não se parecia em nada com ele. (OC I, 1151)

Nada era mais diferente de mim do que essa pintura: eu não era melhor, se se quiser, mas era outro. (id., 1152)

Nas Confessions, sua resposta a isso, como se sabe, é mostrar-se "em toda verdade da natureza". Mas o erro persistiu - mais ainda, agravou-se. O conhecimento de si e do outro, como sugerimos acima, comporta um elemento de juízo valorativo: não se trata apenas de representar a si ou ao outro corretamente, mas julgá-lo corretamente, avaliar justamente o seu valor. Rousseau é particularmente sensível a isso, e essa sensibilidade é ainda agravada com o fato, segundo sua interpretação, de que nos falsos juízos de que se julga o objeto o que está em jogo não são os seus atos, mas, sim, sua pessoa. Não se trata de dizer que seus atos são culpados ou errados, mas de dizer que Jean-Jacques é $\mathrm{mau}^{9}$. É esse elemento que pouco a pouco predomina na preocupação de Rousseau com o desconhecimento de que se sente vítima. A falha das Confessions pode ser entendida então com relação a esse ponto. Lembremos a nota, de tom bastante agressivo, que Rousseau acrescentou ao final de suas leituras públicas das Confessions:

Eu disse a verdade. Se alguém sabe coisas contrárias ao que acabei de expor, mesmo que fossem mil vezes provadas, o que sabe são mentiras e imposturas, e se se recusa a apurá-las e esclarecê-las junto a mim enquanto estou vivo, não ama nem a justiça nem a verdade. De minha parte, declaro em voz alta e sem medo: quem quer que, mesmo sem ter lido meus escritos, examine por seus próprios olhos meu natural, meu caráter, meus costumes, minhas inclinações, meus prazeres, meus hábitos, e possa crer-me um homem desonesto, é, ele próprio, um homem que merecia ser destruído [un homme à étouffer]. (OC I, 656)

9 A distinção entre virtude e bondade, a qual tem papel importante na construção do argumento dos Dialogues (mas que aparece também em outros lugares da obra) é um reflexo dessa preocupação de Rousseau em separar uma apreciação de seus atos e de sua pessoa, de tal modo que, embora errado ou mesmo culpado (ou seja, embora não virtuoso), Jean-Jacques possa ainda ser bom. Sobre essa distinção, ver $O C$ I, 670-71, 774, 823-24, 864; ver tb $\propto$ IV, 817. Essa distinção também tem um lugar destacado na caracterização dos personagens da Nouvelle Héloïse. 
Se não bastasse o próprio tom da segunda parte da obra, essa nota por si só já justificaria o silêncio que, conta Rousseau, foi o único fruto que recolheu de suas leituras públicas. O estremecimento de Mme d'Egmont, reportado por Rousseau no final das Confessions, aparece assim como a única resposta de fato possível nas circunstâncias. Mas isso representa, para Rousseau, o fracasso completo de sua intenção de estabelecer uma nova situação de comunicação com aqueles que, ele pensa, já pronunciaram sobre ele um juízo falso e irrecorrível.

Os Dialogues retomam de zero essa mesma intenção. Rousseau inicia seu texto referindo-se à situação em que pensava estar com relação ao juízo de seus contemporâneos:

Disse freqüentemente que se me dessem de um outro homem as idéias que foram dadas de mim aos meus contemporâneos, eu não me teria comportado com ele do modo como eles o fazem comigo. Essa afirmação deixou a todos bastante indiferentes sobre esse ponto, e não vi em ninguém a menor curiosidade de saber em que minha conduta teria sido diferente da dos outros e quais teriam sido minhas razões. (OC I, 661)

Um novo enfoque do problema do conhecimento de si e do outro, portanto, faz-se necessário, um que dê tanta ênfase ao objeto quanto à forma de proceder com relação a esse objeto. Daí um dos objetivos primários dos Dialogues ser justamente o de oferecer um modelo de conhecimento e julgamento dos homens que resulte em uma apreciação correta e imparcial. Aparecer despido "em toda verdade da natureza" não produziu nenhum efeito. Se não bastou mostrar-se como se é realmente, então deve ser preciso também dizer com que olhos deve-se ser visto: "era preciso necessariamente que eu dissesse com que olho, se eu fosse um outro, eu veria um homem tal como eu sou". (OC I, 665)

Há, portanto, nos Dialogues, um reajuste da perspectiva das Confessions, ao mesmo tempo em que se mantém parte de sua intenção primária. E esse reajuste, vale notar, repercute também no tipo de imagem que é finalmente oferecida ao leitor. A suspeita que envolve cada vez mais radicalmente o olhar do outro determina uma escolha pela nitidez da imagem, mesmo que isso resulte em um certo empobrecimento da análise de si mesmo. Rousseau refere-se constantemente às Confessions como a história de sua alma. A esse histórico, os Dialogues substituem um longo retrato de "Jean-Jacques"10, composto de dois momentos complementares: o relato de "Rousseau", que retrata fielmente "Jean-Jacques" (OC I, 799 ss.) e uma generalização (funci-

10 Usaremos as aspas para referir-nos aos personagens do diálogo. Assim, não se deve confundir "Rousseau" ou "Jean-Jacques", os dois personagens dos diálogos, com Rousseau, autor dos diálogos. 
onando como uma confirmação) desse retrato que o transforma em uma descrição geral do caráter do homem natural (id., 820 ss.). Com relação às Confessions, a representação que Rousseau dá de si mesmo nos Dialogues é significativamente mais fixa. Intencionalmente, o retrato de "Jean-Jacques" é feito para moldar-se ao tipo - ao caráter — do homem natural. Um responde simetricamente ao outro. É sem dúvida significativo que o mesmo homem que, nas Confessions, insistia na "sucessão de afecções", na "cadeia de sentimentos" que formavam essencialmente seu eu e explicavam sua singularidade, diga agora:

De todos os homens que conheci, aquele cujo caráter deriva mais diretamente apenas de seu temperamento é J.J. Ele é o que o fez a natureza: a educação modificouo pouco. Se, desde seu nascimento, suas faculdades e suas forças estivessem de uma só vez desenvolvidas, desde então o teríamos aproximadamente tal como foi em sua maturidade, e hoje, após sessenta anos de penas e misérias, o tempo, a adversidade, os homens muito pouco o modificaram. (OC I, 799-800)

Nada mostra mais a distância entre a perspectiva das Confessions e essa dos Dialogues do que um contraste entre o trecho que acabamos de citar e a famosa passagem do fim do livro IV das Confessions, onde Rousseau diz:

Se eu me encarregasse do resultado e lhe dissesse: tal é o meu caráter, ele [o leitor] poderia crer, senão que eu o engano, ao menos que eu me engano. Mas, detalhando para ele com simplicidade tudo o que me aconteceu, tudo o que fiz, tudo o que pensei, tudo o que senti, não posso induzi-lo em erro, a menos que eu queira, e ainda mesmo que o queira, não conseguiria dessa forma tão facilmente. Cabe a ele reunir esses elementos e determinar o ser que eles compõem; o resultado deve ser sua obra, e se ele se engana então, todo o erro será obra sua. (OC I, 175)

Eis a estratégia que falhou: o erro persistiu — e não adianta muito lançar a culpa sobre o outro. A decisão pela fixidez do caráter $^{l 1}$, nos Dialogues, contra a fluidez da história da alma ${ }^{12}$, mostra a dimensão que ganharam os problemas do dar-se a conhecer para Rousseau.

11 Sobre a noção de caráter, ver VAN DELFT,L. Littérature et anthropologie. Nature humaine et caractère à I'âge classique. Paris: PUF, 1993; KUP PERMAN, Joel. Character. N. York: Oxford UP, 1991; e "Character and Self-Knowledge", Proceedings of the Aristotelian Society, 1984/85, 85, 219-238; FLANAGAN, 0. e RORTY, A. (eds). Identity, Character, and Mbrality. Cambridge (Mass.): The MIT Press, 1990.

12 Sobre a oposição entre "retrato" e "história da alma", as dois modos sob os quais, desde o início, Rousseau pensava altemadamente sua empresa autobiográfica, ver LEJEUNE, P. L'autobiographie en France. Paris: A. Colin, 1971; MACCANNEUL, J.F. "History and self-portrait in Rousseau's autobiography". Studies in Romanticism, 1974, 13, no 4; e STAROBINSKI, J. qo. cit., especialmente págs. 223-225. Ver ainda SAISSEIIN, R.G."Rousseau and portraiture: from representation to fiction". Studies on Voltaire and the Eigthteenth Century, 60, 1968, 201-224; e DIACONOFF, S. "Identity and representation in the prose and painted portrait". French Literature Series: Autobiography in French Literature, 12, 1985, 61-70. 
O problema, então, desde as Confessions, é o de retificar uma opinião que é um juízo - sobre si mesmo, juízo que era percebido como falso e, mais importante, como possuindo um sentido moral, ou um conteúdo valorativo fundamental. O que é acrescentado pelos Dialogues é uma reflexão justamente sobre o "viés", sobre a opinião distorcida, suas causas e motivações. Um dos temas em torno do qual se estruturam os Dialogues, como se sabe, é o tema do complô. Um contraste com a parcialidade do juízo do público pode ajudar-nos a entender o que está em jogo no modelo de juízo que vai ser proposto por "Rousseau" na obra.

"Rousseau" desenvolve seu método em direta oposição ao modo de proceder do "público" ou da "multidão". Seus princípios mais gerais afirmam sempre a necessidade da autonomia do juízo e a suficiência do juízo autônomo, desde que formulado da maneira correta. A primeira regra do método de "Rousseau" diz:

Nas coisas que posso julgar por mim mesmo não tomaria jamais os juízos do público como regra para os meus. (OC I, 682)

Naturalmente, essa oposição está na lógica mesma dos Dialogues que, em boa medida, como já dissemos, são uma longa variação em torno do tema do complô. Desse ponto de vista, o que há exatamente de errado com o juízo do público?

O público, diz Rousseau, "vê apenas aquilo que se quer que ele veja" (OC I, 703). O primeiro problema com o público é sua passividade. Seu olhar precisa, de alguma forma, ser alimentado e o seu juízo vai depender do que lhe for apresentado. Uma das intenções dos Dialogues é justamente mostrar que o que o público "vê" e julga é uma imagem fantástica e quimérica, o "Jean-Jacques" dos Messieurs. Este não resultou de uma apreciação da pessoa e de suas ações, mas, sim, de uma intenção: foi construído, assim como foram deliberadamente distorcidos, segundo pensa Rousseau, os seus retratos pintados (OC I, 777782). O que presidiu a essa intenção e o que mantém o público no erro?

Há duas frentes de combate aqui: primeiro, a "liga" composta de homens e mulheres capazes de formar a opinião; de outro, o público propriamente. Cada um desses grupos está no erro. Mas a razão do engano em cada caso é diferente. Rousseau identifica dois fatores do erro: os preconceitos e as paixões. O preconceito é o erro próprio do público, sempre tão ligeiro, sempre tão disposto a ver o que se quer que ele veja, sempre passivo e maleável:

O espírito humano, naturalmente preguiçoso, gosta de poupar-se trabalho seguindo o pensamento dos outros, sobretudo naquilo que adula suas próprias inclinações. (OC I, 880) 
Perfeitamente adaptado à natureza plástica do público, o preconceito torna-se rapidamente um princípio universal de explicação: "explica-se tudo a partir do preconceito que se tem" (id. 742) ${ }^{13}$. E isso, como não poderia deixar de ser, falseia necessariamente todo o julgamento:

Ver exatamente tal como ele é, um homem de quem se tem de início uma opinião decidida, seja para o bem, seja para o mal, é mais difícil do que vós pareceis acredi$\operatorname{tar}($...). Cada um vê e admite tudo o que confirma seu juízo (...). Vê-se aquilo em que se acredita, não aquilo que se vê. (id., 741/742)

O olhar submetido ao preconceito é necessariamente distorsivo. O preconceito é uma espécie de doença social, uma dessas "epidemias do espírito que se espalham de homem a homem, como uma espécie de contágio" (id., 880), uma espécie de "icterícia universal, fruto de uma bile acre e derramada, que não altera apenas o sentido da vista, mas corrompe os humores e mata enfim totalmente o homem moral, que permaneceria bem constituído sem ela" (id., 881). E não se pode esperar de olhares doentes mais do que imagens falsas, inconstantes, distorcidas: "O mesmo objeto visto em tempos diferentes com olhos diferentemente afetados causam-nos impressões muito diferentes." (id., 742)

É preciso acentuar, porém, o que é de fato o ponto importante para Rousseau nessa denúncia da passividade. A princípio, as flutuações da opinião não são em si mesmas um mal: o mal na verdade começa quando essas flutuações passam a ser dirigidas:

Dentre as singularidades que distinguem este século em que vivemos de todos os outros é o espírito metódico e conseqüente que, há vinte anos, dirige as opiniões públicas. Até aqui essas opiniões vagueavam sem seqüência e sem regra ao sabor das paixões dos homens e essas paixões, entrechocando-se sem cessar, faziam o público flutuar de uma a outra sem nenhuma direção constante. Hoje já não é mais a mesma coisa. Os próprios preconceitos têm seu caminho e suas regras e essas regras, às quais o público está submetido sem que suspeite, estabelecem-se unicamente a partir das intenções daqueles que o dirigem. (id., 964/965) ${ }^{14}$

Antes de se espalhar, o preconceito precisa ser cultivado: essa é a obra das ligas, das seitas, das cabalas, daqueles que Rousseau chama genericamente de les Messieurs, que não se deixam levar pela corrente dos preconcei-

13 au ainda, mais adiante: "Quando se acredita que há nele apenas mal, vê-se nele apenas isso, suas açães boas ou indiferentes logo mudam de aparência com muitos preconceitos e um pouco de intenpretação" (OC I, 901).

14 O germe dessa idéia já estava exposto no preâmbulo de Neuchâtel: "Tant qu'on ne m'a jugé que par mes livres, selon l'intérest et le goût des lecteurs, on n'a fait de moi qu'un être imaginaire et fantastique, qui changeoit de face à chaque écrit que je publiois. Mais quand une fois j'ai eu des emnemis personnels, ils se sont formé des systèmes selon leurs vues, sur lesquels ils ont de conoert établi ma reputation qu'ils ne parvoient taut-à-fait détnuire" (OC I, 1152). 
tos mas, ao contrário, são ativamente movidos por uma paixão. Os Messieurs, ao contrário do público, não são passivos, são inquietos (remuants), são eles próprios os agentes do contágio. Diz Rousseau:

Tudo isso seria verdadeiro se só tivéssemos o erro dos preconceitos a temer. O que aconteceria se se acrescentasse ainda o fascínio das paixões? (...) Faz-se um esforço para achar odioso aquilo que se odeia e se é verdade que o homem com prevenção vê aquilo em que acredita, é ainda mais verdade que o homem com paixão vê aquilo que deseja. (id., 742)

Não se trata mais de um erro baseado em uma crença errada, mas de um erro deliberadamente criado e sustentado como verdade - trata-se de uma mentira. O público enganou-se porque foi enganado, e sua própria natureza, por assim dizer, desculpa-o: "O público, que vê das coisas apenas a aparência, enganado por ela está desculpado" (id., 768). Mas a "liga" tem "interesse em disfarçar a verdade e em ver o que não era" (id., 775). Os Messieurs carregam a culpa da mentira, germe do preconceito.

Assim, a paixão, mais do que a "icterícia" do preconceito, turva o olhar e seduz o julgamento. "Sabe-se a que ponto o ódio fascina os olhos", diz Rousseau. Conhecer - ou seja, julgar - corretamente os homens implica, portanto, manter-se igualmente afastado dos preconceitos e das paixões relativas ao objeto do juízo. Isso define o ponto de partida do método proposto por "Rousseau".

Vamos procurar reconstruir o modelo de juízo proposto por "Rousseau" a partir de dois pontos: as qualidades próprias do "juiz eqüitativo", derivada diretamente da oposição entre o ponto de vista do juiz imparcial e o do público ou dos Messieurs; e os meios concretos para realizar um juízo adequado sobre alguém.

É no contraste com o público e os Messieurs, como já foi sugerido, que as qualidades próprias do juiz eqüitativo ressaltam-se. Ele é, antes de qualquer outra coisa, o homem imparcial. Ao contrário do público, ele vê com os seus próprios olhos e ao contrário dos Messieurs, não é um observador apaixonado. O que o caracteriza primariamente é sua atitude frente ao outro: sua "sinceridade de coração" (775), sua "franqueza" (785), sua "boa-fé" (698, 769), sua "disposição favorável à verdade" (763). Essa insistência na boa-fé, além de apontar para uma dificuldade própria do conhecimento de si e do outro, é uma conseqüência direta da intenção primária dos Dialogues de corrigir os juízos falsos sobre Jean-Jacques. O problema, posto genericamente, é como "ler no coração" de um outro? Como chegar ao que ele "é realmente" a partir do que ele nos parece ser? E como conhecê-lo — isto é, julgá-lo — se não atingirmos o que "realmente é"? O método de "Rousseau" é uma tentativa de solucionar esse problema. 
Suspeitar das aparências implica uma separação forte entre duas esferas da existência individual, uma superficial, aparente, "exterior" e outra profunda, essencial, "interior". Um dos princípios fundamentais do método que "Rousseau" emprega para conhecer "Jean-Jacques" é justamente a atenção a tudo o que pode manifestar a seus olhos o seu interior (cf. OC I, 792). É seu "interior" finalmente que precisa ser conhecido - é seu coração que precisa ser lido -, se queremos de fato conhecê-lo. De todo modo, no entanto, é sempre seu "exterior" que nos é primeiramente acessível. Não é por acaso que "Rousseau" começa sua análise de "Jean-Jacques" pela fisionomia (cf. $777 \mathrm{ss}$ ), logo antes de fazer uma análise de seus retratos pintados ou gravados. O caminho em direção ao que o outro é realmente começa inevitavelmente na superfície a que temos acesso. Mas mesmo aqui é preciso distinguir. Às oposições exterior/interior e ser/aparência sobrepõe-se uma terceira entre "signos passageiros" ou "signos equívocos e rápidos" (cf. 783) e a "constante maneira de ser" (cf. 784, 792, 795). E é essa maneira constante de ser que finalmente "revela infalivelmente um caráter" (792).

Quase sempre é mais fácil determinar o que o outro não é do que o que ele é realmente. $\mathrm{O}$ que o indivíduo não é realmente é determinado, antes de mais nada, por alguns elementos socialmente impostos: o interesse, como observa Saint-Preux a respeito da sociedade parisiense, substitui o caráter como princípio explicativo da coerência, da constância das ações; o amorpróprio limita a imaginação, a espontaneidade, a originalidade e impõe o conformismo e a homogeneidade. Mas o homem também não é aquilo que é deliberadamente manipulado pela vontade com a única intenção de criar para os outros uma imagem fictícia de si mesmo. "Rousseau" afirma sua desconfiança das ações brilhantes, feitas como que em um palco com a intenção de ofuscar e desviar a atenção (cf. 783). Essas duas observações levam "Rousseau" a enunciar outro princípio fundamental de seu método:

(...) a ocasião mais rara e mais segura para conhecer bem um homem (...) é a de estudálo à vontade em sua vida privada, vivendo, por assim dizer, consigo mesmo. (OC I, 785) Tendo minhas primeiras investigações me envolvido nos detalhes de sua vida, apeguei-me particularmente a isso, persuadido de que tiraria para meu objetivo esclarecimentos mais seguros daí do que de tudo que ele poderia ter dito ou feito em público e que, de resto, eu não vi por mim mesmo. É na familiaridade de um comércio íntimo, na continuidade da vida privada, que um homem a longo prazo deixa-se ver tal como é; é quando a força da atenção sobre si mesmo relaxa que, esquecendo-se do resto do mundo, a gente se livra ao impulso do momento. (id., 794)

Essa escolha pela vida privada revela um ponto importante. O que "Rousseau" quer é buscar a perspectiva que mais se aproxima daquela que cada um pode ter sobre si mesmo. Sua finalidade é a de "penetrar, se possível, dentro 
dele ["Jean-Jacques"] mesmo" (OC I, 783) - e vale lembrar que intus et in cute era a epígrafe das Confessions, a expressão que Rousseau escolheu para resumir toda sua intenção. Todo o esforço de Rousseau nos Dialogues vai justamente no sentido de encontrar uma tal perspectiva, uma que alie a exterioridade da terceira pessoa ao alcance privilegiado da primeira pessoa.

Da forma como o método de "Rousseau" está exposto no segundo diálogo, segui-lo é quase impraticável fora do caso particular a que se aplica e da situação fictícia que constitui seu pano de fundo. O próprio "Rousseau" é o primeiro a notá-lo:

Este método é seguro, mas longo e penoso: exige paciência e uma assiduidade que só o verdadeiro zelo pela justiça e pela verdade pode sustentar e que se dispensa facilmente, substituindo as observações lentas, mas sólidas, que um exame igual e seguido permite por qualquer observação fortuita e rápida. (OC I, 794)

Nesse sentido, é o terceiro e último diálogo que (no que concerne, antes de mais nada — mas não só - o caso específico de Jean-Jacques, que é, afinal, o objeto primário do livro) dá a chave de toda a obra. Rousseau está convencido de que vai sobreviver por suas obras. Seu nome e seus livros, ele está certo, já adquiriram uma vida própria, independente da sua vida individual. Mas essa certeza é apenas fonte de mais angústia: Rousseau estava atormentado pela idéia de que a posteridade tivesse dele uma imagem tão falsa e distorcida quanto a que seus contemporâneos, segundo ele pensava, tinham. Mas onde mais poderia a posteridade encontrar o verdadeiro Jean-Jacques senão nas suas próprias obras? Essa é a conclusão a que aponta o terceiro diálogo. Com efeito, a conversão do "Francês" dá-se decisivamente pela leitura das obras e não pela freqüentação de "Jean-Jacques"15. Diante do convite de "Rousseau" de, como ele, fazer uma visita a "Jean-Jacques", o "Francês" responde:

Vós pretendeis que eu deva ir ver J.J para verificar com meus olhos o que vós me
haveis dito e o que eu próprio inferi da leitura de seus escritos. Essa confirmação é
supérflua e sem recorrer a ela sei desde já o que pensar sobre esse ponto. (OC I, 939)
Não, Senhor, não tenho necessidade de ver J.J para saber o que pensar sobre ele. (id.,
942)

O exemplo da "conversão" do "Francês" no terceiro diálogo dá-nos uma nova pista de como ver a direção a que aponta a obra como um todo — tanto os Dialogues quanto a própria obra de Rousseau em geral. R. Ellrich já havia

15 Sobre isso, ver ainda REIS, C., q. cit. , pp. 48-51. 
notado que Rousseau está constantemente à espera de um leitor idea ${ }^{16}$. Ora, é justamente em torno do tema da leitura que está estruturado o terceiro diálogo. Se relermos agora o segundo diálogo retrospectivamente, é possível ver também ali o tema da leitura dando sustentação ao texto. Já fizemos referência ao uso freqüente por Rousseau da expressão "ler os corações". Uma outra noção importante que surge em conexão com o tema da leitura é, justamente, a noção de caráter, a que já fizemos referência acima. E tudo isso remete àquilo que Rousseau sempre considerou como o grande objetivo de toda sua obra: permitir, através dela (mas também através de seu exemplo pessoal), que os homens "leiam" em seu próprio coração, conheçam a si mesmos e, através disso, conheçam a verdadeira natureza humana, ouvindo a voz da consciência (que é a voz da natureza). E a voz da consciência repete sempre: o homem é naturalmente bom.

Como, então, segundo os Dialogues, devemos fazer para garantir um juízo correto sobre alguém? Devemos, antes de mais nada, pensar por nós mesmos, evitando assim o erro típico do "público". Devemos também esforçarmo-nos para evitar a todo custo a prevenção provocada pelas paixões e pelo amor-próprio, o que era o erro (erro agora mais grave, porque fruto de uma intenção de fazer mal) dos Messieurs. Devemos ainda separar o que é aparente do que é real, o que é superficial do que é profundo, o que é passageiro e contingente do que é permanente e constante. Sobretudo, o que é, em certo sentido, condição para todo o resto, devemos ser capazes de pôr-nos "na pele" do outro em algum sentido.

Mas isso ainda é pouco para entendermos o que está envolvido no juízo sobre o valor moral de uma pessoa. Como freqüentemente em Rousseau, a compreensão desse ponto passa pela compreensão do lugar e do papel da sensibilidade. Para tentar esclarecer o que está em jogo nesse movimento em direção ao conhecimento e ao julgamento adequado dos outros, vamos, antes de concluir, examinar mais três figuras de observadores e julgadores de homens que encontramos na obra de Rousseau: o Emílio adolescente, entrando na cena do mundo; Saint-Preux em Paris; e Wolmar.

Cada exemplo põe um problema específico e, deste modo, completam-se uns aos outros. Tomemos, inicialmente, o exemplo de Émile. No ponto em que nos interessa, Émile começa a "sentir seu ser moral" e o problema que se põe a ele, em conseqüência, é o de "estudar-se em suas relações com os homens" (OC IV, 493). Mas para isso, diz Rousseau mais adiante, é preciso cumprir antes um requisito: “é preciso começar por conhecer o coração humano" (id., p. 
525). Ora, Émile, como se sabe, é uma das figuras do homem natural - ou seja, seu contato com a natureza é, podemos dizer, imediato, confunde-se com a experiência que tem de si mesmo. Émile, olhando dentro de seu próprio coração, vê intacta a natureza humana e a partir dela tira seu padrão:

Que ele saiba que o homem é naturalmente bom, que ele o sinta, que julgue seu próximo a partir de si mesmo. (OC IV, 525)

Émile está a salvo do que Rousseau chama em outro lugar de a "dupla ilusão do amor-próprio" - mesmo porque, por definição, ainda está, a esta altura de sua formação, livre dos aspectos negativos do amor-próprio. Tendo em seu coração a medida do humano em sua pureza original, pode, a princípio, julgar sem erro os outros a partir de si mesmo. Mas se para ele não se põe o problema da "dupla ilusão", é justamente aí que surge um outro, oposto, mas curiosamente semelhante. No primeiro preâmbulo das Confessions, Rousseau denunciava aquele que se faz a regra de tudo e vê apenas a si mesmo em toda parte. Ora, não é exatamente o que acontece agora com Émile? Certamente, ao contrário da vítima dos poderes de ilusionista do amor-próprio, Émile parte de uma experiência de si mesmo que não se distingue da experiência do universal. Ao tirar de si mesmo a regra, a escala para medir o humano, Émile age legitimamente. Mas aqui surge seu problema específico, o aprendizado que lhe cabe agora. A "ordem moral" em que está entrando agora é uma hierarquia de posições e de lugares, uma ordem de preferências cujo primeira característica - ou, mesmo, cujo princípio constitutivo - é a desigualdade $^{17}$. Émile logo vai-se dar conta de que há uma disparidade entre o que sente em si mesmo sobre o homem e os comportamentos que observa entre os homens. A conclusão que vai tirar dessa distância, a maneira como vai interpretá-la, é um destes pontos críticos em que toda a sua vida moral e toda a sua felicidade, segundo Rousseau, é posta em jogo: uma falsa conclusão e a negatividade do amor-próprio instala-se soberanamente, com toda a sua corte de vícios. Há mais de um tipo possível de conclusão, cada uma delas produzindo um efeito diferente sobre o indivíduo e determinando diferentemente sua relação com os demais — assim como há mais de um tipo de observadores dos homens, diz Rousseau:

Não são os filósofos os que melhor conhecem os homens; eles enxergam apenas através dos preconceitos da fillosofia, e não conheço nenhum outro estado em que se têm tantos preconceitos. Um selvagem julga-nos mais retamente do que o faz um

17 Ver, p. ex., a descrição do surgimento da estima pública na segunda parte do Discaurs sur l'origine de l'inégalité (OC III, 169). 
filósofo. Esse sente seus vícios, indigna-se com os nossos e diz para si mesmo: somos todos maus; o outro nos olha sem emocionar-se e diz: vós sois loucos. Ele tem razão, pois ninguém faz o mal pelo mal. Meu aluno é esse selvagem, com esta diferença: Emílio, tendo refletido mais, comparado mais idéias, visto nossos erros de mais perto, mantém-se em guarda contra si mesmo e julga apenas sobre o que conhece. (OC IV, 535)

Émile é o "selvagem feito para habitar as cidades". Rousseau espera que, como aquele outro selvagem, seu julgamento sobre os homens seja um diagnóstico da loucura deles. Jean-Jacques ele próprio já tinha chegado ao mesmo diagnóstico, o que o lançou em seu longo projeto terapêutico. Émile não foi educado para tornar-se um filósofo, mas sua percepção da loucura humana tem também um efeito sobre ele: muito mais do que o desprezo ou o ódio, será movido em direção aos homens pela piedade.

Em vista, portanto, da necessidade de se chegar a uma conclusão correta, o (re)conhecimento da bondade natural do homem tem de vir acompanhada de sua contrapartida, sem o que essa conclusão seria necessariamente falsificada:

Que ele saiba que o homem é naturalmente bom (...); mas que ele veja como a sociedade deprava e perverte os homens, que ele encontre nos preconceitos deles a fonte de seus vícios; que ele seja levado a estimar cada indivíduo, mas que despreze a multidão, que veja que todos os homens vestem mais ou menos a mesma máscara, mas que saiba também que há rostos mais bonitos do que a máscara que os cobre. (OC IV, 525)

Um pouco antes, Rousseau já observava:

Para guiá-lo nesta busca, após tê-lo mostrado os homens a partir dos acidentes comuns à espécie, é preciso agora mostrá-los a ele a partir de suas diferenças. Aqui entra a medida da desigualdade natural e civil e o quadro de toda a ordem social. (OC IV, 524)

O problema de Émile, portanto, define-se assim: ele conhece o "coração humano" (que deve ser tomado aqui no seu alcance universal, como referindo-se à natureza humana e ao princípio da bondade natural) e sabe reconhecer em cada um a medida da humanidade — sabe reconhecer-se a si mesmo nos outros. Mas, na ordem moral, a experiência que tem de afrontar é a da diferença, da desigualdade. O aprendizado que lhe cabe, assim, é justamente o aprendizado da desigualdade - e, em especial, o de um subproduto dela, a dissimulação.

Tratando-se agora de ver por sob as máscaras, "conhecer o coração humano" ganha um sentido mais restrito. Não basta mais apenas conhecer a natureza humana para conhecer os homens. Da mesma forma, se a experiên- 
cia que Émile tem de si mesmo basta para o primeiro conhecimento, o segundo está além de toda a experiência que já teve. Nesta medida, é preciso fornecer-lhe essa experiência, com o cuidado, no entanto, de administrar os efeitos que possa ter sobre seus sentimentos - em particular, sobre os sentimentos que o movem em direção aos outros e que vão determinar suas relações com eles. Rousseau diz:

\begin{abstract}
Nesse intuito, importa tomar um caminho oposto ao que seguimos até aqui e instruir o jovem antes pela experiência dos outros do que por sua própria experiência. Se os homens o enganam, ele os odiará; mas se, respeitado por eles, ele os vê enganaremse mutuamente, terá piedade deles. O espetáculo do mundo, dizia Pitágoras, assemelha-se ao dos jogos olímpicos. Uns têm ali um negócio e pensam apenas em seu lucro; outros empenham-se pessoalmente e buscam a glória; outros contentam-se em ver os jogos, e esses não são os piores. (OC IV, 525)
\end{abstract}

O que Rousseau propõe inicialmente é transformar Émile em um espectador. Para conhecer os homens, diz Rousseau, é preciso vê-los agir. É na ação (eventualmente em sua relação com o discurso) que os homens se descobrem. Mas Émile necessita de uma experiência atenuada, transformá-lo muito cedo em observador pode ser fatal. Além do mais, convém manter a distância e evitar o envolvimento, sobretudo através das paixões e do interesse, que podem provocar o desejo de participar da ação. Émile deve ser, por enquanto, um puro espectador. Eis aí, diz Rousseau, o momento da história (cf. OC IV, 526). Um pouco mais tarde será também o momento das fábulas, quando de espectador Émile tiver que passar gradualmente a ator (cf. OC IV, 540ss). Mais adiante, ainda teremos ocasião de retomar essas metáforas "espectatoriais" em conexão com o problema do teatro.

O exemplo da iniciação de Émile na arte de observar os homens estabelece, assim, um primeiro ponto, que diz respeito ao objeto propriamente que deve ocupar o observador dos homens: são as ações que se apresentam em primeiro lugar como objetos de observação. A razão para isso é que as ações podem ser mais reveladoras do "interior" do indivíduo do que, por exemplo, os discursos ou a fisionomia. O problema de Émile — ir além da aparência - é o mesmo já encontrado por "Rousseau". A consideração das ações permite ultrapassar a linha que separa "exterior" e "interior": a partir delas é possível chegar-se a motivos e intenções e, a partir da maneira como eles se estruturam e se combinam com as paixões e desejos, é possível enfim determinar o "verdadeiro caráter". E Rousseau faz aqui a mesma qualificação importante, já vista no método de "Rousseau", relativa ao tipo de ações mais significativas. As mais significativas devem ser, naturalmente, as que mais revelam o homem, ou seja, aquelas que não se detêm na superfície e que apontam, na sua origem, para os elementos mais profundos e 
marcantes do caráter. "É nas bagatelas que o natural se descobre", diz Rousseau (OC IV, 530).

Mas o exemplo de Émile é, afinal, limitado, da mesma forma como a história mostrou-se, no final das contas, limitada no que diz respeito às possibilidades de se conhecer os homens. Essa limitação foi imposta pela necessidade, que Rousseau, por sua vez, impôs a si mesmo, de considerar Émile exclusivamente como espectador. Era preciso, como vimos, mostrar os homens à distância, sem que Émile pudesse sentir-se ao alcance de um possível envolvimento pela ação. Émile deve ser puro espectador e Rousseau consegue manter essa qualidade em seu pupilo confrontando-o apenas com personagens históricos. Mas e quando é esse justamente o caso, ou seja, quando se trata de mover-se em uma situação de que o observador pode eventualmente participar - e, às vezes, deve participar? O próprio Rousseau reconhece a limitação da perspectiva exclusiva do espectador: para tornar Émile um observador dos homens completo, capaz de aproveitar realmente de suas observações, diz ele, é preciso torná-lo também ator:

Vós haveis também começado a torná-lo ator para torná-lo espectador, é preciso rematar: pois da platéia vêem-se os objetos tais como parecem, mas da cena vêemse tais como são. Para abranger o todo é preciso pôr-se em perspectiva, é preciso aproximar-se para ver os detalhes. (OC IV, 542)

Mas para essa transformação de espectador em ator, Rousseau vai ainda recomendar, no caso de Émile, uma intermediação através das fábulas. Para avançarmos um pouco mais a respeito das qualidades do observador dos homens, é preciso buscar outros exemplos. Os exemplos de Saint-Preux e de Wolmar, na Nouvelle Héloïse, reparam a limitação do Émile e, pelo confronto dos tipos, jogam nova luz sobre a questão. É para eles que nos voltamos agora.

Quando chega em Paris, Saint-Preux não é um noviço na arte de observar os homens. Já tivera ocasião de exercitá-la, por exemplo, no seu relato da viagem ao Valais (carta XXIII da $1^{\text {a }}$ parte). No entanto, o que encontra na grande cidade é algo tão absolutamente novo, homens tão radicalmente outros que lhe parecem pertencer a outra espécie. Sua experiência desse novo meio e dessa (por assim dizer) nova humanidade segue duas etapas e desemboca, finalmente, em um fracasso. Vamos segui-la, antes de confrontá-la com o exemplo do judicioso Wolmar.

O que Saint-Preux experimenta em Paris é um dos efeitos mais perniciosos, segundo Rousseau, da desigualdade, um efeito que atinge as relações entre os homens e, a partir daí, afeta a própria integridade dos indivíduos: a dissimulação. A primeira reação de Saint-Preux em Paris é a de estranha- 
mento, mais do que de desorientação. Não se trata apenas da experiência de um provinciano na capital, mas do conflito entre duas estruturas radicalmente opostas das disposições humanas - conflito sentido por Saint-Preux como tão radical que interrompe momentaneamente o circuito do reconhecimento, inibe sua capacidade de reconhecer o outro como seu semelhante. A primeira carta de Paris começa com a plena constatação desse estranhamento:

Entro com horror neste vasto deserto do mundo. Este caos oferece-me apenas uma solidão horrível, onde reina um morno silêncio. Minha alma apressadamente tenta expandir-se e encontra-se por todo lado limitada. Nunca estou menos só do que quando estou só, dizia um antigo; eu só estou sozinho na multidão, onde não posso ser nem teu nem dos outros. Meu coração gostaria de falar, ele sente que não é escutado. Gostaria de responder; nada é dito que pudesse chegar até ele. Não entendo a língua do país e ninguém aqui entende a minha. (OC II, 231)

Saint-Preux experimenta a pura exterioridade. Os indivíduos que observa não lhe aparecem como homens: às vezes confundem-se com suas vestes ("Quando um homem fala, é, por assim dizer, suas vestes e não ele que tem um sentimento", id., 233); são "máquinas que não pensam e que são movidas por molas" (id., 234); são como figuras em um "quadro vivo" (id., 235); são "larvas e fantasmas" ou máscaras que, talvez, não recubram nenhum rosto (id., 236). Daí a antítese inicial que Saint-Preux utiliza para expressar como sente sua posição no mundo: a companhia de máscaras, de fantasmas ou de máquinas não pode ser uma verdadeira sociedade ${ }^{18}$. Formado por esses seres, o mundo não pode ser outra coisa senão um deserto.

Da mesma forma, sendo pura exterioridade, esses indivíduos não possuem propriamente um caráter. A marca que distingue eventualmente um indivíduo de outro não é função de seu caráter, mas de sua pertença a um ou outro grupo. A marca própria de seu caráter é substituída pela filiação a um interesse:

Não é necessário conhecer o caráter das pessoas, mas somente seus interesses, para adivinhar mais ou menos o que dirão sobre cada coisa. (id., 233)

Tem-se apenas que se informar sobre suas sociedades, suas associações, sobre seus amigos, sobre as mulheres que vêem, sobre os autores que conhecem: a partir disso pode-se estabelecer seus sentimentos futuros sobre um livro prestes a ser lançado e que eles não leram, sobre uma peça prestes a ser encenada e que eles não viram, sobre tal ou qual autor que eles não conhecem, sobre tal ou qual sistema de que não fazem nenhuma idéia. (id., 234)

18 Sobre a idéia de uma sociedade de seres mecânicos, ver REIS, C., "Sensibilidade e sociabilidade em Jean-Jacques Rousseau", Kriterion, vol. 41, n. 101, 2000, pp. 46-85. 
Essa redução à pura exterioridade, mais o fato de que não possuem um caráter próprio, um princípio interior de unidade que garanta a sua coerência, resulta em que "cada um põe-se sem cessar em contradição consigo mesmo" (id., 234). A desarticulação (Saint-Preux usou a palavra "caos") entre o que se pensa e o que se diz, entre o que se diz e o que se faz é a regra. Saint-Preux conclui:

Assim, os homens com quem falamos não são aqueles com quem conversamos; seus sentimentos não partem de seus corações, suas luzes estão em seus espíritos, seus discursos não representam seus pensamentos, percebe-se deles apenas a figura (...). (id., 235)

Saint-Preux, no entanto, não desespera completamente: talvez seja ainda possível superar a situação de estranhamento e, enfim, encontrar rostos humanos. Ele diz:

Tal é a idéia que me formei sobre a grande sociedade que vi em Paris. Essa idéia é talvez mais relativa à minha situação particular do que ao verdadeiro estado de coisas e será revista sem dúvida sob novas luzes. (id., 235)

A segunda etapa da experiência de Saint-Preux em Paris é justamente a busca de um modo próprio para conhecer esses homens cujo ser parece estar totalmente na aparência. De início, pareceria bastar aplicar o princípio, já exposto no primeiro preâmbulo das Confessions, de separar o adquirido do natural. Esse princípio é de fato reafirmado por Saint-Preux:

O primeiro inconveniente das grandes cidades é que os homens tornam-se ali outros do que são, e que a sociedade lhes dá, por assim dizer, um ser diferente do que é o seu. Isso é verdadeiro sobretudo em Paris e sobretudo das mulheres que tiram dos olhares dos outros a única existência com que se preocupam. (...) Ora (...) em geral não há o que ganhar com o que se substitui à natureza. Mas nós nunca a apagamos inteiramente; ela escapa sempre por algum lugar e a arte de observar consiste em uma certa habilidade em captá-la. (OC II, 273)

Mas o problema é mais complexo. É possível que a natureza esteja tão radicalmente negada que se torne, nas circunstâncias em que se põe o observador, irreconhecível. Sob a crítica de Julie, Saint-Preux tenta reformular o alcance de seu projeto: não se trata de conhecer os franceses, isto é, de determinar seu caráter nacional, mas de algo mais amplo:

Meu objetivo é conhecer os homens e meu método é estudá-lo em suas diversas relações. Não o vi até agora senão em pequenas sociedades, esparsas sobre a terra. Vou agora considerá-lo amontoado em multidões nos mesmos lugares e começarei a julgar a partir disso os verdadeiros efeitos da sociedade; pois se é constante que ela 
torne os homens melhores, quanto mais numerosa e próxima for, mais eles devem valer, e os costumes, por exemplo, serão muito mais puros em Paris do que no Valais; se encontramos o contrário, é preciso tirar a conseqüência oposta. (id., 242) ${ }^{19}$

Mas a dificuldade não se resolve totalmente ampliando-se o alcance da observação. O homem "amontoado em multidões" continua sendo um objeto fugidio. Saint-Preux lamenta-se a Julie:

Como tudo é apenas aparência vã e tudo muda a cada instante, não tenho tempo para emocionar-me [d'être ému] com nada, nem o tempo de examinar nada. (id., 245)

Saint-Preux enuncia aqui uma limitação séria. Há mais do que uma dificuldade de comunicação, há uma barreira quase intransponível entre o observador e seu objeto de observação. O observador, incapaz de "ser tocado" (d'être ému) por seu objeto, é também incapaz de conhecê-lo plenamente, isto é, de superar o estranhamento e reconhecer nele algum traço de comunidade. Ora, dissemos que o ponto de partida de todo juízo sobre os homens é a experiência que o indivíduo tem de si mesmo - mas essa aplicação da experiência própria ao outro tem naturalmente como condição o estabelecimento (ou o reconhecimento) de uma espécie de identidade: o outro precisa de algum modo ser percebido como semelhante. A esse problema sobrepõe-se ainda um outro, de perspectiva:

Assim começo a ver as dificuldades do estudo do mundo, e não sei nem mesmo que lugar é preciso ocupar para bem conhecê-lo. O filósofo está muito afastado dele, o homem do mundo, próximo demais. Um vê demais para poder refletir, o outro pouco demais para poder julgar o quadro total. Cada objeto que afeta o filósofo é por ele considerado à parte, e, não podendo discernir nem as ligações nem as relações com outros objetos que estão fora de seu alcance, ele não o vê nunca em seu lugar e não percebe nem sua razão nem seus verdadeiros efeitos. O homem do mundo vê tudo e não tem tempo para pensar em nada. A mobilidade dos objetos permite-lhe apenas percebê-los, não os observar; eles se anulam mutuamente com rapidez e só lhe restam impressões confusas que se assemelham ao caos. (id., 245-246)

Entre a perspectiva do filósofo, que seria naturalmente a sua, e a do homem do mundo, que, até por razões sociais, está-lhe vedada, Saint-Preux precisa encontrar sua via. Seu último recurso para resolver seus impasses é

19 Essa conclusão sobre a natureza dos efeitos da sociedade não é finalmente tirada explicitamente por Saint-Preux, mas é mais do que evidente que Rousseau esperava de seu leitor que a tirasse ele próprio. De certo modo, essa é a única conclusão concreta a que podem chegar as observações de Saint-Preux, que de resto fracassa em seu objetivo de conhecer os homens do monde. Mas seu fracasso é, finalmente, significativo: que seja impossível conhecer o homem do monde para além da mascára, que seja inevitável sofrer, nas grandes cidades, os efeitos corruptores da sociedade, são juízos precisos sobre a irrealidade do primeiro e sobre a perversidade da segunda. 
recorrer à ação. "É loucura querer estudar o mundo como simples espectador", diz ele. "Não se vê os outros agirem a não ser na medida em que se aja" (id., 246). Mas a distância entre o jovem plebeu provinciano sem experiência e os homens e mulheres ultra-refinados da grande sociedade parisiense faz-se sentir agora e não lhe deixa maiores possibilidades reais de ação. Resta-lhe plenamente aberto apenas o caminho da atuação, da representação:

Exercito-me tanto quanto me é possível em tornar-me polido sem falsidade, complacente sem baixeza e em tomar aquilo que há de bom na sociedade de modo que posso ser aceito nela sem adotar seus vícios. (id. 246)

Isso, no entanto, está fadado ao fracasso. Este processo mimético reproduz o funcionamento do monde. Como para o ator, não basta manter-se distanciado dos vícios do personagem que representa: é a própria arte de representar, diz Rousseau na Lettre à d'Alembert, que está comprometida essencialmente com o vício - é o vício por excelência. Mas, do ponto de vista do objetivo de Saint-Preux de estudar os homens, também falha. Engajar-se nesse processo mimético é finalmente reduzir a si mesmo à espessura da máscara e, no limite, renunciar a qualquer esperança de encontrar rostos humanos. Representando no meio de marionetes, Saint-Preux não vai mais uma vez conseguir enxergar além do véu de uniformidade que recobre a ação no mundo:

Todo mundo faz a mesma coisa na mesma circunstância: tudo segue um tempo, como os movimentos de um regimento em batalha: diríeis que são marionetes pregadas sobre a mesma tábua ou movidas pelo mesmo fio.

Ora, como não é possível que toda essa gente que faz exatamente a mesma coisa esteja afetada da mesma maneira, é claro que é preciso penetrá-los por outros meios para conhecê-los; é claro que todo esse jargão é apenas um vão formulário e serve menos para julgar sobre os costumes do que sobre o tom que reina em Paris. (id., 250/251)

Quais são esses meios, Saint-Preux deixará Paris sem descobri-lo ${ }^{20}$. Sua experiência termina na suspensão do julgamento:

Assim, seja de que modo encaremos as coisas, tudo aqui é apenas tagarelice, jargão, conversas sem conseqüência. No palco, como no mundo, pode-se muito bem escutar o que se diz, nada se aprende sobre o que se faz, e o que se tem necessidade de aprender? tão logo um homem tenha falado, está-se informado sobre sua conduta, não fez ele tudo, não está julgado? o homem de bem [l'honnête homme] daqui não é aquele que faz boas ações, mas aquele que diz belas coisas, e um único dito inconsiderado, solto sem reflexão, pode trazer àquele que o fez um mal irreparável que não

20 É interessante notar que, logo depois de afirmar a necessidade de encontrar novos meios para conhecer
o homem do monde, Saint-Preux não só silencia sobre esses outros meios, mas começa uma digressão sobre o teatro. 
seria apagado por quarenta anos de integridade. Em uma palavra, ainda que as obras dos homens não se assemelhem a seus discursos, vejo que não se os pinta a não ser por seus discursos, sem atenção às suas obras; vejo também que em uma grande cidade a sociedade parece mais doce, mais fácil, mais segura mesmo do que entre gente menos estudada; mas os homens lá são de fato mais humanos, mais moderados, mais justos? Não sei. São apenas aparências, e sob esses exteriores tão abertos e tão agradáveis os corações são talvez mais escondidos, mais enterrados do que os nossos. Estrangeiro, isolado, sem negócios, sem ligações, sem prazeres e querendo depender apenas de mim, como julgar? (id. 254/255)

Será preciso, então, acolher a lição de que o verdadeiro sábio aceita as aparências como realidade e que "a mais sublime sabedoria consiste em viver como os loucos" (id., 255)? Saint-Preux acha-se impotente diante da "evidência" com que se prova essa afirmação - o que aponta para um fracasso mais profundo, mais perigoso da sua experiência: perigosamente, ele é afetado por ela intimamente, começa a partir dela a transformar-se em sua essência:

No entanto começo a sentir a embriaguez em que essa vida agitada e tumultuada mergulha aqueles que a levam e caio em um atordoamento semelhante àquele de um homem diante de cujos olhos faz-se passar rapidamente uma multidão de objetos. Nenhum dos que me afetam interessa meu coração, mas todos juntos o perturbam e suspendem seus afetos, a ponto de esquecer por alguns instantes o que sou e a quem pertenço. Cada dia ao sair de casa fecho meus sentimentos à chave para usar outros que se prestem aos frívolos objetos que me esperam. Insensivelmente julgo e raciocino como ouço todo mundo julgar e raciocinar. (id. 255)

Longe de consolidar seu conhecimento do homem através do conhecimento dos homens do mundo, o que Saint-Preux experimenta é a própria degradação da natureza humana nesse homem "amontoado em multidões":

Forçado a mudar assim a ordem de minhas afecções morais; forçado a dar um preço a quimeras e a impor silêncio à natureza e à razão, vejo assim desfigurar este divino modelo ${ }^{21}$ que trago dentro de mim e que servia ao mesmo tempo de objeto para meus desejos e de regra para minhas ações, flutuo de capricho em capricho e por estarem meus gostos sujeitos à opinião, não posso estar um único dia seguro sobre o que amarei no dia seguinte.

Confuso, humilhado, consternado por sentir degradar em mim a natureza do homem e de ver-me assim tão rebaixado daquela grandeza interior em que nossos corações elevavam-se reciprocamente, volto à noite penetrado por uma secreta tristeza, oprimido por um desgosto mortal, o coração vazio e inchado como um balão cheio de ar. (id., $255 / 256)^{22}$

21 Năo é muito claro se esse divin modele é a própria natureza (ou a consciência) ou se é Julie e seu amor por ela. Mas a referência à natureza humana no parágrafo seguinte permite escolher a primeira interpretação.

22 Que a sua experiência foi afinal um fracasso está perfeitamente ilustrado pelo episódio em que SaintPreux é levado, sem seu conhecimento prévio, a uma soirée chez les filles. Ao dar-se conta da armadilha 
O fracasso de Saint-Preux está finalmente ligado menos às suas origens sociais do que ao fato de que representa o homem sensível por excelência. Sua capacidade de conhecer e julgar os homens está, em certa medida, em relação direta com a possibilidade de estender (répandre) sua alma, como diz no início da carta XIV (p. 231). Mas talvez o verdadeiro observador dos homens, aquele capaz de "ler no coração" de qualquer outro, seja aquele que pode reconhecer a humanidade mesmo no ponto mais baixo de corrupção. No Émile, Rousseau já observava:

O que será preciso para bem observar os homens? Um grande interesse em conhecêlos, uma grande imparcialidade para julgá-los. Um coração suficientemente sensível para conceber todas as paixões humanas e suficientemente calmo para não as experimentar. (OC IV, 536)

Essa descrição parece feita sob medida para M. de Wolmar, que Julie apresenta assim:

O maior gosto de M. de Wolmar é o de observar. Ele ama julgar os caracteres dos homens e das ações que ele vê. Ele os julga com uma profunda sabedoria e a mais perfeita imparcialidade. (OC II, 370)

Dois traços caracterizam recorrentemente o personagem de Wolmar: seu gosto pela observação e sua frieza. Wolmar define a si mesmo (e é definido pelos demais) sempre como um homem sem paixões - no que é o perfeito oposto, portanto, do apaixonado Saint-Preux. De que maneira essa ausência de paixões determina a forma como conhece os homens? Esse é o problema que nos põe a figura de Wolmar.

Tanto a definição do Émile quanto a descrição de Julie chamam a atenção para um mesmo ponto: a imparcialidade. A definição do observador dos homens no Émile, em particular, afirma a necessidade de conciliar o interesse em conhecer com a imparcialidade em julgar. É essa aliança justamente que Wolmar vai ilustrar: seu gosto pela observação é acompanhado, por um lado, pela vasta experiência e, por outro, pela ausência de paixões, o que lhe garante satisfazer a dupla exigência de conhecê-las sem senti-las. Essa é a raiz de sua imparcialidade - bem como, diga-se de passagem, de sua peculiar autoridade.

Saint-Preux queixava-se, como vimos, de que a mobilidade dos objetos e das situações a que estava exposto no mundo não lhe dava tempo de "ser

em que caíra, resolve consagrar a noite à sua "função de observador". Mas, mais uma vez, deixa-se levar pela corrente e acaba, embriagado, entre os braços "de uma dessas criaturas". Ver carta XXVII, 2a parte. 
tocado" (être ému) por eles. "Ser tocado" pelo objeto é então uma condição para conhecê-lo? ${ }^{23}$ Esse é um ponto que mereceria ser mais desenvolvido. Por enquanto, notemos apenas que Saint-Preux sofre de uma espécie de miopia típica das "almas sensíveis". É o que Claire diz a Julie:

Eis o que deve acontecer a todas as almas de uma certa têmpera; elas transformam por assim dizer os outros em si mesmas; elas têm uma esfera de atividade na qual nada lhes resiste: não se pode conhecê-las sem querer imitá-las e de sua sublime elevação elas atraem para si tudo o que as circundam. É por isso, minha cara, que nem tu nem teu amigo conhecereis jamais os homens; pois vós os vereis antes como vós os fareis ser do que como eles mesmos são. Vós dareis o tom a todos os que viverem convosco; eles evitar-vos-ão ou tornar-se-ão vossos semelhantes e tudo o que vós tereis visto não terá talvez nada de parecido no resto do mundo. (OC II, 204) $)^{24}$

Wolmar, homem sem paixões, está como que isento disso que Rousseau chama de sensibilidade moral, poder que age tanto atrativa quanto repulsivamente $^{25}$. A melhor descrição de seu temperamento em relação ao seu gosto pela observação é feita pelo próprio Wolmar:

Tenho naturalmente a alma tranqüila e o coração frio. Sou desses homens que se crê insultar ao dizer que não sentem nada; quer dizer, que eles não têm paixão que os desvie de seguir o verdadeiro guia do homem. Pouco sensível ao prazer e à dor, experimento apenas fracamente mesmo aquele sentimento de interesse e de humanidade que nos apropria os afetos de outro. Se sofro ao ver sofrer as pessoas de bem, a piedade não contribui com nada para isso, pois não sofro ao ver sofrer os maus. Meu único princípio ativo é o gosto natural da ordem e o concurso bem combinado do jogo da fortuna e das ações dos homens agrada-me exatamente como uma bela simetria em um quadro ou como uma peça bem dirigida no teatro. Se tenho alguma paixão dominante é a da observação: amo ler nos corações dos homens; como o meu me engana

23 Descrevendo "Jean-Jacques", "Rousseau" diz, no 20 Dialogue: "De beaux sons, un beau ciel, un beau paysage, un beau lac, des fleurs, des parfums, de beaux yeux, un doux regard; tout cela ne réagit si fort sur ses sens qu' après avoir percé par quelque côté jusqu'à son cour" (OC I, 807). Embora o contexto seja diferente, o princípio que aparece aqui é semelhante: o circuito do conhecimento não se completa sem a mediação da imaginação e do sentimento. A memória também vai ter um papel importante nessa apropriação aprofundada dos dados primários do conhecimento. Falando agora na primeira pessoa, diz Rousseau nas Confessions: "J'ai étudié les hormes et je me crois assez bon observateur. Cependant je ne sais rien voir de ce que je vois; je ne vois bien que ce que je me rappelle, et je n'ai de l'esprit que dans mes souvenirs. De tout ce qu'on dit, de tout ce qu' on fait, de tout ce qui se passe en ma présence, je ne sens rien, je ne pénétre rien. Le signe extérieur est taut ce qui me frappe. Mais ensuite taut cela me revient: je me rappelle le lieu, le tems, le ton, le regard, le geste, la circonstance, rien ne m'échappe. Alors sur ae qu' on a fait ou dit je trouve ce qu'on a pensé, et il est rare que je me trompe" (OC I, 114/115) .

24 Isso parece mais verdadeiro de Julie do que de Saint-Preux. Ao longo de todo o ramance, o étrange empire de Julie é recorrentemente afirmado (ver, p. ex., @C II, pp. 122, 203, 409, 444, 559, 585, 607, 639, 642 , 678). A influência de Wolmar vai ser de natureza diferente: Wolmar muda as almas, não provocando o desejo de imitação, mas através de uma "técnica terapêutica" cuidadosamente pensada.

25 Referindb-se a Saint-Preux, diz Wblmar: "Quant à moi qui n'ai ni sistêmes ni préjugés, je suis sûr qu'il ne me hait point naturellement. Aucum horme ne me hait; un horme sans passion ne peut inspirer d'aversion à persome" (OC II, 429). O que vale para o ódio deve valer também para o amor: Julie jamais amará Wolmar como ama Saint-Preux. A distinção entre sensibilité physique e sensibilité morale está em $\propto C ~ I, 805$. 
pouco, como observo com sangue frio e sem interesse e como uma longa experiência deu-me sagacidade, não me engano em meus juízos (...). (OC II, 490/491)

Embora esse discurso de Wolmar dê margem a uma série de possíveis comentários, queremos aqui destacar apenas três pontos. O primeiro diz respeito à caracterização da insensibilidade de Wolmar. Qualquer leitor do segundo Discours e do Émile não poderia deixar passar sem reflexão a referência de Wolmar à piedade. Wolmar diz que não é movido pela piedade (após afirmar, como antecedente, sua pouca sensibilidade ao prazer e à dor) e isso significa, na maneira como ele próprio se expressa, que é incapaz de apropriar-se das afecções dos outros. O elemento de empatia, que no exemplo de Saint-Preux aparecia como uma condição da possibilidade de "ler o coração" do outro - e, ao mesmo tempo, na medida em que a situação em que se encontrava reduzia os efeitos dessa empatia, como um obstáculo à compreensão do homem do mundo - desaparece aqui. Daí, o que é nosso segundo ponto, que para Wolmar a maneira como vê e julga os homens é em todos os pontos semelhante ao que experimenta em um teatro. Wolmar é em todos os sentidos um ser excepcional. Para ele — e só para ele - a analogia entre juízo moral e situação teatral funciona sem qualificações. Se todos fôssemos "Wolmares", não haveria necessidade de uma denúncia do poder do teatro, como a tentada na Lettre à d'Alembert. Por fim, devemos destacar a conclusão de seu discurso. Três elementos concorrem na sua correta apreensão dos homens: em primeiro lugar, seu coração "engana-o pouco"; também Wolmar, como Rousseau no primeiro preâmbulo das Confessions, não é vítima da "dupla ilusão" do amor-próprio; seu acesso a si mesmo é límpido, perfeito. Em segundo lugar, ele "observa de sangue-frio e sem interesse"; seu interesse no conhecimento dos homens é fruto de um gosto quase estético, é uma espécie de interesse "desinteressado"; não há uma motivação egoísta, de interesse próprio, o que combina perfeitamente com a exigência de imparcialidade. Por fim, Wolmar acentua sua "longa experiência" — mais uma vez, tal como Rousseau no primeiro preâmbulo.

De todos os personagens peculiares que compõem a galeria de tipos não pouco estranhos de Rousseau, Wolmar é talvez o mais singular. A excepcionalidade de sua quase insensibilidade deveria fazer de seu exemplo também uma exceção. Sua perfeita imparcialidade e a justeza de seus juízos estão afinal ancorados, fundamentados nessa excepcionalidade. Mas isso mesmo também ajuda a esclarecer o que está implicado pelo juízo de valor que fazemos uns sobre os outros. Para concluir, vamos procurar sistematizar os elementos sugeridos em cada exemplo examinado, de modo a ter um quadro geral do que está envolvido no tipo de juízo moral que nos interessou aqui. 
Conhecer e julgar os outros pede que o observador ponha-se no lugar e na distância adequados. Pede que seja imparcial. Agora, como entender essa imparcialidade? O exemplo de "Rousseau" nos Dialogues estabelece que ser imparcial envolve, por um lado, pensar por si mesmo (ou seja, envolve eliminar os preconceitos, os "ídolos do foro"); por outro, envolve eliminar o efeito pernicioso das paixões e, particularmente, das formas negativas do amorpróprio. A eliminação dos preconceitos é, dos dois pontos, o menos problemático: trata-se de uma correção necessária da forma como as coisas (no caso, os outros) são percebidos. O segundo ponto, por sua vez, levanta as questões mais interessantes. De fato, os exemplos de Saint-Preux e Wolmar chamam atenção, de formas diferentes, para o papel da sensibilidade no tipo de juízo de valor que vem nos interessando aqui. Vimos como Saint-Preux, o homem sensível por excelência, como sugerimos, confrontado com a situação extrema de Paris, vê frustrada sua intenção de conhecer adequadamente os homens nessa situação (e, portanto, também de apreciá-los ou julgá-los adequadamente). E essa frustração foi provocada, em última análise, por sua incapacidade de ser "tocado" pelo objeto de suas observações: o circuito de reconhecimento e apreciação é interrompido pelo excesso de sensibilidade negativa encontrada por Saint-Preux em Paris. Wolmar, por sua vez, é, ao contrário, o homem insensível: conhece e aprecia corretamente os homens sem, no entanto, a necessidade de ser "tocado" por eles. Mas tanto SaintPreux como Wolmar são extremos: Saint-preux pela situação em que se encontra, Wolmar por sua própria natureza.

Mas terá Wolmar falhado tal como falhou Saint-Preux? Que tenha falhado parece claro pelo final do romance (embora sua falha mais grave tenha sido como "terapeuta", não exatamente como observador; mas, afinal, no caso de Wolmar, uma coisa está ligada à outra). E, se falhou, sua falha está, em alguma medida, ligada à sua insensibilidade. Temos, assim, portanto, SaintPreux falhando por sua sensibilidade, Wolmar falhando por sua insensibilidade. Seja como for, Rousseau está sugerindo que a correta apreciação do outro passa por um determinado estado (uma determinada afinação) da sensibilidade. O que faltou igualmente nos casos opostos de Saint-Preux e Wolmar foi o movimento de expansão que, em última instância, liga um indivíduo ao outro - e, finalmente, permite uma apreciação adequada dele. O "Rousseau" dos Dialogues ilustra bem isso: é o meio termo entre os dois extremos de SaintPreux e Wolmar - e, portanto, mais do que Wolmar, encarna a figura do juiz imparcial - porque é capaz de reconhecer em "Jean-Jacques" um semelhante (ao contrário de Saint-Preux em Paris, que se vê diante de uma forma humana que é incapaz de reconhecer como tendo algo em comum com qualquer coisa que já tenha experimentado) e isso pelo efeito que as idéias de "Jean-Jac- 
ques" provocam (ao contrário de Wolmar, cuja insensibilidade, de alguma forma, torna-o incapaz de entender plenamente aquela linguagem do "mundo ideal", compreendida apenas por aqueles cujos corações foram feitos para isso).

A imparcialidade necessária para o correto juízo sobre o outro (um juízo sobre o seu valor), assim, não envolve distanciamento: ao contrário, exige aquele misto de reconhecimento e identificação que Rousseau resumiu em sua idéia de "expansão". Daí o sentido de sua crítica ao teatro. O que a representação teatral põe em jogo são as próprias potências morais de julgamento, que envolvem, em seu funcionamento, as forças que compõem mais essencialmente o indivíduo - forças como a imaginação, por exemplo. O teatro, de certa maneira banalizando os mecanismos envolvidos no juízo moral, acabam por ameaçar a integridade moral do indivíduo em sua raiz. Não se trata apenas do perigo de ter os sentidos despertados pela imaginação nem da tentação eventual de imitar o vício que se dá em espetáculo (nem de tomá-lo pela virtude): o perigo é mais profundo. Freqüentemente esquecemos que Rousseau, em sua crítica impiedosa, leva o teatro muito mais a sério do que todos aqueles autores que leram sua carta a d'Alembert apenas no registro da polêmica e arvoraram-se em defensores dos espetáculos. "Quanto mais reflito", diz Rousseau, "mais eu acho que tudo o que se representa no teatro não é aproximado, é afastado de nós". Na situação teatral interrompe-se, entre espectador e personagem, o circuito do reconhecimento, como ocorreu com Saint-Preux no grande palco de Paris. No teatro, a única possibilidade aberta ao espectador é, em última análise, a de identificar-se ou reconhecer-se no personagem, com o risco de ele próprio vir a tornar-se uma espécie de personagem, o que significa, para Rousseau, uma corrupção radical de sua sensibilidade. O que não funciona na situação teatral é o mecanismo da expansão: o espectador é levado para fora de si mesmo pela imaginação; mas a expansão da sensibilidade, que estabelece propriamente um laço entre os indivíduos, isso está ausente. A ilusão teatral, por mais completa e eficaz, mantém sempre presente uma distância entre espectador e personagem.

Rousseau lança-se em seu empreendimento autobiográfico em parte porque está convencido de que seus contemporâneos não o vêem como ele realmente é (não o apreciam segundo seu real valor). Isso não é, diga-se de passagem, senão outra maneira de dirigir contra a sociedade da época as mesmas acusações que desde o primeiro Discurso Rousseau vinha acumulando contra ela - especialmente a denúncia dos efeitos mais perniciosos do amorpróprio em seus sentidos mais negativos (amor-próprio que é a encarnação mesma da parcialidade). De nada adiantou, como vimos rapidamente: o desnudamento das Confessions, longe de reverter a opinião dos outros, resultou 
no silêncio. A tentativa, nos Dialogues, de mostrar a perspectiva do juiz eqüitativo e o que ela implica também resulta em silêncio e incompreensão, se lembrarmos agora os tristes eventos que se seguiram à conclusão da obra. Nas Rêveries, finalmente, Rousseau parece abandonar a esperança de fazerse ouvir e entender. Diante do fracasso da tentativa de fixar a perspectiva imparcial do juiz eqüitativo, nos termos sugeridos nas obras anteriores, ao eu, só sobre a terra, incapaz de encontrar aquele que seria capaz de expandir-se a ponto de pôr-se também em seu lugar, resta apenas a fruição de si mesmo.

\section{Bibliografia}

DIACONOFF, S. "Identity and representation in the prose and painted portrait". French Literature Series: Autobiography in French Literature, 12, 1985, 61-70

ELLRICH, Robert. Rousseau and his reader, The Rhetorical Situation of the Major Works. Chapell Hill: University of North Carolina Press, 1969

FLANAGAN, O. e RORTY, A. (eds). Identity, Character, and Morality. Cambridge (Mass.): The MIT Press, 1990.

FOUCAULT, Michel, "Introduction“, em Rousseau juge de Jean-Jacques. Paris: A. Colin, 1962

GRIMSLEY, Ronald. Jean-Jacques Rousseau, A Study in Self-Awareness. Cardiff: University of Wales Press, 1961

KUPPERMAN, Joel. Character. N. York: Oxford UP, 1991

. "Character and Self-Knowledge", Proceedings of the Aristotelian Society, 1984/85, 85, 219-238

LEJEUNE, P. L'autobiographie en France. Paris: A. Colin, 1971

MACCANNELL, J.F. "History and self-portrait in Rousseau's autobiography”. Studies in Romanticism, 1974, 13, no 4

REIS, Claudio A.. "Filosofia e terapia". Kriterion, vol. 39, n. 98, julho a dezembro de 1998, pp. 37-76

"Sensibilidade e sociabilidade em Jean-Jacques Rousseau", Kriterion, vol. 41, n. 101, 2000, pp. 46-85.

ROUSSEAU, Jean-Jacques. Euvres complètes, Bibliothèque de la Pléiade. Paris: Gallimard, 1959-1995

SAISSELIN, R.G. "Rousseau and portraiture: from representation to fiction". Studies on Voltaire and the Eigthteenth Century, 60, 1968, 201-224

STAROBINSKI, J. La transparence et l'obstacle, Paris: Gallimard, 1971

VAN DELFT, L. Littérature et anthropologie. Nature humaine et caractère à l'âge classique. Paris: PUF, 1993 